\title{
PEMANFAATAN POTENSI SAMPAH RUMAH TANGGA SEBAGAI SUMBER ENERGY LISTRIK MENGGUNAKAN TEKNIK THERMAL CONVERTER
}

\author{
Eza Bintang Ramadhan ${ }^{1}$, \\ Program Studi Pendidikan Fisika Universitas Jember \\ Email: ezabintangramadhan@gmail.com \\ Sudarti ${ }^{1}$ \\ Program Studi Pendidikan Fisika Universitas Jember \\ Email: sudarti.fkip@unej.ac.id
}

\begin{abstract}
S : The problem of waste in the territory of Indonesia is quite high due to the large number of people in Indonesia. One of them is household waste. The amount of household waste that is increasingly piling up and not being processed or utilized properly and correctly results in these problems. Various kinds of household waste are often encountered such as wet waste, dry waste, organic waste and inorganic waste. With these problems, a solution was found to utilize this household waste as a source of electrical energy by using a thermal converter technique. The purpose of writing this article is to suppress the accumulation of household waste which can later be used as a source of electrical energy that is safe for the environment. In writing this article the author uses the article review method. The method of collecting data in this article is by reviewing articles from several existing reference journals. The data taken from the writing of this article is the potential source of electrical energy from the utilization of household waste using thermal converter technology. The results obtained from the use of this thermal converter technology are the efficiency that works for each thermal converter technology used. Then the potential resulting from the use of this thermal converter technology produces greater electrical energy with the use of an increasing number of household waste as well.
\end{abstract}

Keyword: Potential Waste, Household Waste, Electrical Energy, Thermal Converter Techniques

ABSTRAK: Permasalahan sampah di wilayah Indonesia tergolong cukup tinggi yang diakibatkan dari banyaknya jumlah penduduk di Indonesia. Salah satunya sampah yang berasal dari rumah tangga. Banyaknya sampah rumah tangga yang semakin menumpuk dan tidak diolah atau dimanfaatkan secara baik dan benar mengakibatkan terjadinya permasalahan tersebut. Berbagai macam sampah rumah tangga yang sering ditemui seperti sampah basah, sampah kering, sampah organik dan sampah anorganik. Dengan adanya permasalahan tersebut ditemukan solusi untuk memanfaatkan sampah rumah tangga ini sebagai sumber energy listrik dengan menggunakan teknik thermal converter. Adapun tujuan dari penulisan artikel ini adalah untuk menekan penumpukan sampah rumah tangga yang nantinya bisa digunakan sebagai pemenuhan sumber energy listrik yang aman bagi lingkungan. Dalam penulisan artikel ini penulis menggunakan metode review artikel. Cara pengumpulan data pada artikel ini yaitu dengan review artikel dari beberapa jurnal referensi yang ada. Data yang diambil dari penulisan artikel ini yaitu potensi sumber energi listrik dari hasil pemanfaatan sampah rumah tangga dengan menggunakan teknologi thermal converter. Hasil yang didapatkan dari penggunaan teknologi thermal converter ini yaitu efisiensi yang bekerja untuk tiap teknologi thermal converter yang digunakan. Kemudian potensi yang dihasilkan dari penggunaan teknologi thermal converter ini menghasilkan energy listrik yang semakin besar dengan penggunaan jumlah sampah rumah tangga yang semakin banyak juga.

Kata Kunci: Potensi Sampah, Sampah Rumah Tangga, Energy Listrik, Teknik Thermal Converter

\section{PENDAHULUAN}

S ampah merupakan suatu benda yang tidak digunakan lagi yang dapat dirasakan, diraba, dan dilihat oleh mata telanjang. Kasus permasalahan sampah banyak sekali terjadi di wilayah Indonesia, terutama sampah rumah tangga. Sampah rumah tangga ini semakin banyak akibat dari jumlah penduduk Indonesia yang semakin tinggi. Sampah menimbulkan banyak dampak dalam kehidupan sehari-hari. Mulai dari dampak positif maupun dampak negative. Namun, kerap kali sampah banyak mengandung dampak negative akibat tidak dikelola dengan baik. Dampak ini berakibat pada lingkungan yang menjadi kotor dan menimbulkan penyakit kepada masyarakat.

Masyarakat menganggap bahwa sampah merupakan barang yang tidak penting bagi sebagian orang, walaupun sumber energy alternative dapat diperoleh dari sampah. Namun, kandungan sampah organic sekitar 70,69\%, yang akan meningkat menjadi sekitar 53,7 juta ton ditahun ini. Pada saat yang sama, di kota-kota besar, 600-830 gram sampah dihasilkan tiap harinya. Dari tahun ke tahun, peningkatan jumlah penduduk mengakibatkan penigkatan jumlah sampah yang melebihi kapsitas

\footnotetext{
1 Program Studi Pendidikan Fisika Universitas Jember
} 
pelayanan dan infrastruktur sanitasi perkotaan. Oleh karena itu, banyak sekali masyarakat yang mencari jalan keluar dengan membakar sampah atau biasanya dibuang ke sungai, yang justru akan semakin merusak lingkungan [13].

Berdasarkan (UU-18/2008) sampah rumah tangga didefinisikan sebagai sampah yang berasal dari aktivitas kehidupan sehari-hari di dalam rumah tangga, dimana feses atau tinja dan sampah yang spesifik tidak termasuk kedalamnya [17]. Kebanyakan sampah rumah tangga dikelola untuk beberapa hal. Misalnya peningkatan kesehatan lingkungan dalam masyarakat, perlindungan sumber daya alam (air), pelindung dalam fasilitas social ekonomi, dan penunjang pembangunan dalam sector strategis. Namun, sampah rumah tangga ini bisa dijadikan sebagi sumber energy alternative yang berpotensi sebagai sumber energy listrik. Berikut merupakan gambar dari sampah rumah tangga yang ada di masyarakat.

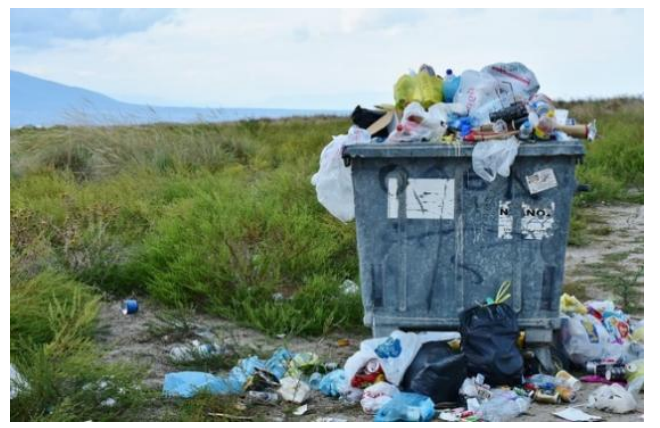

Gambar 1. Sampah Rumah Tangga

(Sumber: https://dlhk.jogjaprov.go.id/pengelolaan-sampah-rumah-tangga)

Menurut para ahli, limbah atau sampah didefinisikan sebagai suatu benda yang sudah tidak memiliki nilai guna atau barang yang tidak bernilai sebagai tujuan biasa maupun yang utama dalam pembuatan atau penggunaan barang yang rusak, atau bahkan bahan yang berlebihan atau ditolak atau dibuang. Sampah atau limbah ini biasanya dihasilkan dari beberapa aktivitas manusia dalam kesehariannya. Namun, terkadang sampah atau limbah ini juga dapat dihasilkan dari proses alam dalam bentuk padat.

Sampah dapat diketahui memberikan dampak permasalahan bagi pemerintah. Sampah sendiri merupakan sisa yang sudah dibutuhkan lagi oleh manusia yang mana bersumber dari berbagai aktivitas yang dilakukan oleh manusia sendiri. Sampah dapat digolongkon menjadi beberapa jenis bentuk diantaranya cair, padat, lumpur maupun berbentruk gas. Banyaknya sampah yang dihasilkan dari aktivitas masyarakat memunculkan ide berbagai pihak untuk mengurangi timbunan daripada sampah. Pengurangan timbunan sampah bertujuan untuk mengurangi masalah dari masyarakat, pemerintah, maupun dunia karena masalah sampah sendiri merupakan masalah yang dialami oleh seluruh negara di dunia. Beberapa upaya telah dilakukan untuk mengurangi timbunan sampah diantaranya penerapan prinsip 3R (Reduce, Reuse, Recycling). Prinsip ini telah lama diterapkan di berbagai negara tetapi tidak memberikan efek yang besar bagi peningkatan timbunan sampah. Penyebab dari tidak terwujudnya tujuan dari 3R adalah tingkat dari kesadaran masyarakat yang masih rendah (Sari 2021).

Dalam kajiannya, sampah tegolong ke dalam 2 jenis berupa sampah organik dan anorganik. Sampah organik didefinisikan sebagai sampah yang dapat dipecah menjadi organisme yang lebih kecil dan yang nantinya tidak memiliki bau, biasanya ciri-ciri ini merupakan ciri-ciri dari kompos. Kompos diartikan sebagai hasil dari penguraian dari organisme organik misalnya sampah, alang-alang jerami, daun-daun kering, dan jenis organisme lainnya. Dimana dalam proses penguraiannya bisa dipercepat dengan adanya bantuan dari manusia. Sampah ini biasanya sampah yang asalnya dari sayur-sayuran, buahbuahan, atau ikan. Berikut merupakan gambar dari sampah organik: 


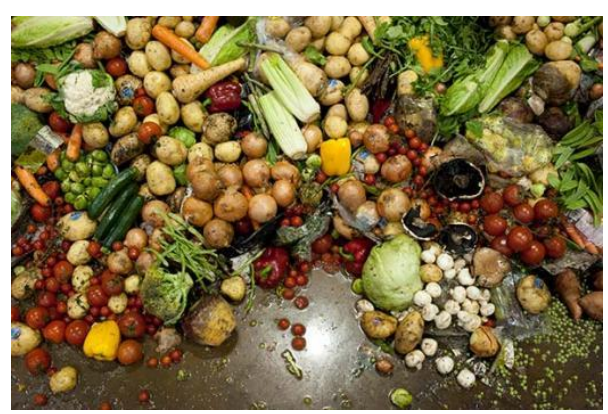

Gambar 2. Sampah Organik

(Sumber: Anima, 2018)

Sedangkan, sampah anorganik merupakan sampah yang cocok didaur ulang, hal ini dikarenakan kita bisa mengelolanya menjadi kerajinan tangan dan menjualnya untuk membantu ekonomi pengrajin. Berikut gambar dari sampah anorganik:

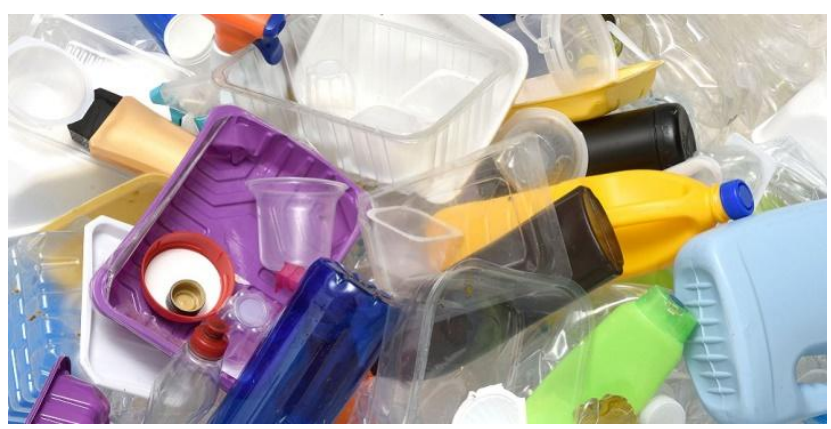

Gambar 3. Sampah Anorganik

(Sumber: Putri, 2020)

Kebanyakan dari pengrajin sampah, lebih memilih untuk mengelola sampah anorganik karena mereka mengolah sampah tersebut menjadi kerajinan tangan. Adapun hasil dari kerajinan tangan tersebut bisa memperoleh penghasilan yang menguntungkan juga. Hal lainnya, pengarajin biasanya membantu mengurangi sampah anorganik yang bisa berbahaya bagi lingkungan. Hal ini dikarenakan sampah tidak dapat terurai secara alami, sehingga sampah anorganik ini bisa didaur ulang menjadi barang yang bermanfaat bagi masyarakat dan memiliki nilai ekonomis bagi para pengrajinnya.

Beberapa usaha telah dilakukan pemerintah maupun dunia untuk mengurangi penggunaan energi berbahan dasar minyak. Pemakaian energi berbahan dasar minya secara terus - menerus akan mengurangi cadangan energi yang di miliki Indonesia di masa yang akan datang. Usaha yang dilakukan pemerintah antara lain, pembangunan pembangkit listrik tenaga surya, pembangkit listrik tenaga angin, dan pembangkit listrik mikrohidro, yaitu pembankit listrik jenis terbarukan. Sekarang telah dikembangkan sumber energi primer pembangkit listrik berbahan dasar pemanfaatan sampah.

Sampah menjadi permasalahan pokok di kota - kota besar seluruh Indonesia. Volume dari sampah sendiri semakin meningkat dan tidak terkendali. Akan tetapi, tempat pembuangan akhir (TPA) daripada sampah terbatas sehingga menjadi persoalan yang harus ditangani lebih lanjut oleh pemerintah (, and . 2017).

Menurut Gunawan et al. (2018) menyatakan bahwa energi merupakan isu yang sangat penting bagi semua negara. Segala macam cara disebabkan oleh beberapa peneliti dalam memperoleh energi terbarukan untuk menggantikan energi berbahan dasar minyak. Salah satu sumber energi alternatif adalah dengan mengolah sampah rumah tangga berupa plastic tersebut sebagai sumber energy untuk membangkitkan listrik [3]. Listrik merupakan salah satu sumber energy kebutuhan yang paling di cari saat ini untuk dipakai dalam kehidupan sehari-hari. Untuk menambah kebutuhan akan listrik yang semakin melonjak, dapat digunakan sampah rumah tangga yang bisa berpotensi sebagai sumber energy alternative terbarukan yaitu sumber energy listrik. Limbah dari sampah dapat diproyeksikan serta dimanfaatkan menjadi sumber energi baru yaitu pembangkit tenaga listrik atau energi listrik. Kita mengenalnya dengan sebutan Pembangkit Listrik tenaga Sampah (PLTSa). Hal ini akan mengurangi permasalahan pemerintah yaitu jumlah limbah sampah yang dihasilkan setiap aktivitas dari manusia 
berbanding lurus dengan tingkat konsumsi manusia akan bahan atau material yang digunakan setiap harinya (Ambabunga 2019).

Energi terbarukan merupakan salah satu jenis energi alam yang dapat digunakan secara langsung dan gratis [9]. Hal lainnya, ketersediaan energi terbarukan ini tidak terbatas dan dapat digunakan selama keberlangsungan hidup. Salah satu hal yang bisa digunakan sebagai sumber energy listrik merupakan pemanfaatan dari sampah. Adanya fakta yang menunjukkan bahwa sampah bisa dimanfaatakan menjadi potensi sumber energy listrik dengan menggunakan teknik thermal converter.

Pembangkit listrik tenaga sampah atau pembangkit listrik sampah atau pembangkit listrik tenaga biomasa sampah didefinisikan sebagai pembangkit listrik thermal dengan uap supercritical steam. Pembangkit ini berbahan bakar sampah atau gas sampah dari methan. Sampah atau gas methan dari sampah dibakar lalu akan menghasilkan panas yang akan memanaskan uap pada boiler steam supercritical (Ambabunga 2019).

Berdasarkan paparan yang telah dijelaskan sebelumnya, banyaknya kasus permasalahan sampah rumah tangga yang jarang dimanfaatkan atau dikelola dengan baik. Maka, sampah rumah tangga bisa berpotensi sebagai sumber energi alternative terbarukan. Adapun tujuan dari penulisan artikel ini untuk menekan penumpukan sampah rumah tangga yang nantinya sampah rumah tangga tersebut bisa digunakan sebagai pemenuhan sumber energy listrik yang aman bagi lingkungan. Akibar dari potensi sampah rumah tangga yang besar dan belum ada pengelolaan yang baik, maka pemanfaatan sampah rumah tangga ini dapat digunakan sebagai sumber energy listrik yang sangat besar potensinya untuk direalisasikan dengan menggunakan teknik thermal converter.

\section{METODE PENELITIAN}

Metode penelitian dalam artikel ini adalah review artikel. Metode review artikel merupakan serangkaian penelitian dengan metode pengumpulan data terkait literatur yang didapatkan melalui pencarian secara online yaitu google scholar. Literatur yang terkait berdasarkan kata kunci potensi sampah, sampah rumah tangga, energy listrik dan teknik thermal converter. Terdapat sebelas artikel yang digunakan sebagai acuan dalam pembuatan artikel ini. Pemilihan artikel berdasarkan tema yang sesuai dan dibutuhkan oleh penulis yaitu tentang sumber energy yang berpotensial seperti sampah rumah tangga. Ada rentang tahun terbit dalam mencari artikel yaitu 5 tahun terakhir. Proses ekstrasi data dilakukan dengan mengelompokkan variabel yang akan diteliti, kemudian mengelompokkan beberapa data dengan melihat seberapa besar listrik yang dibangkitkan.

\section{Pengertian Sampah Rumah Tangga}

\section{HASIL PENELITIAN DAN PEMBAHASAN}

Sumber limbah yang digunakan untuk penelitian kali ini yaitu sampah pemukiman atau sampah rumah tangga. Sampah rumah tangga adalah sampah yang berasal dari sisa - sisa aktivitas rumah tangga, seperti buah - buahan, sayuran, atau sisa dari makanan. Beberapa jenis sampah rumah tangga diantaranya yaitu sampah basah, sampah kering, sampah organik dan sampah anorganik. Sampah basah adalah sampah dengan bahan organik yang bisa membusuk atau berasal dari sisa makanan dan potongan sisa hewan. Sampah bisa dikategorikan sebagai sampah basah jika sampah tersebut mengandung banyak air. Hal inilah yang menyebabkan sampah basah lebih cepat membusuk dan menimbulkan bau aroma yang tidak sedap. Sampah kering yaitu sampah yang berasal dari logam maupun non logam. Biasanya untuk logam seperti kaleng bekas makanan atau minuman. Sedangkan untuk yang non logam sendiri seperti kertas, plastik, kaca. Sampah organik yaitu sampah yang bisa terurai secara alami, contohnya seperti sisa sayuran, sisa buah - buahan yang sering dijumpai pada limbah rumah tangga. Sedangkan untuk sampah anorganik adalah sampah yang tidak bisa terurai secara alami, contohnya seperti plastik, kaleng yang dalam penguraiannya membutuhkan penanganan khusus. Sampah - sampah ini bisa dipergunakan sebagai bahan alternatif untuk menggantikan energi gas alam, minyak bumi dan panas bumi yang dapat digunakan sebagai pembangkit listrik.

Menurut UU No. 18 Tahun 2008 tentang pengelolaan sampah yaitu meliputi : a. Pemilahan dalam bentuk pengelompokan serta pemisahan sampah sesuai dengan jenis, jumlah, dan/atau sifat sampah; b. pengumpulan dalam bentuk pengambilan dan pemindahan sampah dari sumber sampah ke tempat penampungan sementara atau tempat pengolahan sampah terpadu; c. pengangkutan dalam bentuk membawa sampah dari sumber dan/atau dari tempat penampungan sampah sementara atau dari tempat pengolahan sampah terpadu menuju ke tempat pemrosesan akhir; d. pengolahan dalam bentuk mengubah karakteristik, komposisi, dan jumlah sampah;dan/atau e. pemrosesan akhir sampah dalam 
bentuk pengembalian sampah dan/atau residu hasil pengolahan sebelumnya ke media lingkungan secara aman (Suhada, R.T dan Al-Mahdy, I. 2016).

\section{Pengolahan Sampah Rumah Tangga Menggunakan Teknologi Thermal Converter}

Teknologi Thermal Converter merupakan suatu alat dimana pengolahan sampahnya dengan menggunakan sedikit bahan bakar diawal pembakaran, yang mana pada proses tersebut semua jenis limbah yang dibakar dalam waktu sangat cepat akan dimusnakan. Panas yang dihasilkan dari proses pembakaran kemudian didinginkan dengan sirkulasi semprotan air untuk menghasilkan "Superheated Steam”, yang akan ditampung dalam boiler. Kemudian tenaga uap di boiler akan menggerakkan kincir, lalu kincir akan menggerakkan generator untuk menghasilkan energi listrik (Partha, 2010).

Sampah di daerah perkotaan di Indonesia sebagian besar terdiri dari kertas, daun - daunan, makanan, kayu, karet, bekas tekstil, logam, kulit, plastik, kaca dan lain - lain. Sampah sebagian besar berasal dari sampah rumah tangga dan juga sampah pasar tradisional di Indonesia. Sampah - sampah tersebut digolongkan menjadi sampah organik dan sampah anorganik. Sampah organik adalah sampah yang bisa dikatakan sebagai sampah ramah lingkungan. Hal itu dikarenakan jenis sampah organik bisa diolah kembali menjadi suatu yang bermanfaat bila dikelola dengan tepat. Selain itu, sampah organik mudah terurai sehingga tidak terlalu mencemari lingkungan dan merusak lapisan tanah. Sebagian besar berasal dari tanaman yaitu berupa kayu, dedaunan, maupun sudah dalam berbentuk bahan lain seperti kertas, kain, dan makanan sisa. Sedangkan sampah anorganik adalah sampah yang sudah tidak bisa dipakai lagi. Karena sampah anorganik susah diuraikan, maka sampah anorganik yang tertimbun tanah dapat menyebabkan pencemaran tanah karena sampah anorganik tergolong sampah dengan zat yang susah diurai. Jika sampah anorganik tertimbun dalam tanah dalam waktu yang cukup lama, maka dapat menyebabkan rusaknya lapisan tanah. Sebagian besar berasal dari benda-benda yang tidak digunakan lagi dan susah diuraikan, seperti plastik, botol / kaleng minuman, kresek, ban bekas, besi, kaca, kabel, barang elektronik, dan lain sebagainya. Berikut komposisi sampah secara umum yang ada di kota - kota besar Indonesia, rata - rata sebagai berikut :

Tabel 1. Komposisi rata - rata sampah yang ada di kota - kota besar di Indonesia

\begin{tabular}{|c|c|c|c|}
\hline Bahan & $\mathbf{\%}$ & Bahan & $\mathbf{\%}$ \\
\hline Daun, sampah kayu & 70,5 & Plastik & 14,2 \\
Sisa makanan & 12 & Karet & 0,2 \\
Kertas & 0,5 & Kain & 1,3 \\
Kaca logam & 0,7 & dll & 0,5 \\
\hline
\end{tabular}

Sumber : http:/www. Pikiran Rakyat.com

Dari tabel 1. ditas, dapat ditnjau bahwa sampah kota di Indonesia sebagian besar berasal dari sampah tanaman dan proses pengolahan yang cocok adalah proses pengolahan dengan menggunakan thermal konverter. Samapah - sampah tersebut sebelumnya akan disortir dan tidak menutup kemungkinan bahwa bahan - bahan seperti plastik dan juga karet dapat dibakar. Nilai besarnya kalor yang dihasilkan dapat ditentukan dari komposisi unsur - unsur yang terdapat di dalam sampah.

Tabel 2. Analisis bahan bakar asal tanaman

\begin{tabular}{|l|c|}
\hline \multicolumn{1}{|c|}{ Bahan } & $\begin{array}{c}\text { Bahan asal tanaman dalam \% } \\
\text { berat }\end{array}$ \\
\hline Karbon & 45,0 \\
Oksigen & 43,0 \\
Hidrogen & 5,5 \\
Nitrogen & 2,1 \\
Sulfur & 0,1 \\
Fosfor & 0,2 \\
Lain - lain & 4,1 \\
\hline
\end{tabular}

Persamaan stokiometri untuk pembentukan hasil pembakaran yang didapat dari tabel 2. Menjadi seperti persamaan berikut ini : 
$\mathrm{C}+\mathrm{H}_{2}+\mathrm{O}_{2}+\mathrm{N}_{2}+\ldots . . . \longrightarrow \mathrm{CO}_{2}+\mathrm{H}_{2} \mathrm{O}+\mathrm{N}_{2}+\ldots \ldots$.

(Partha 2010).

Proses konversi secara thermal terjadi pada suhu yang relatif tinggi, sehingga proses ini menyebabkan struktur kimia bahan yang diproses berubah. Proses konversi thermal berperan dalam mengurangi jumlah limbah. Hal ini bisa mengurangi tempat penggunaan lahan, namun pengolahan limbah termal masih membutuhkan tempat untuk menangani berbagai residu. Proses thermal bisa memungkinkan perbaikan energi dari limbah, memungkinkan perbaikan mineral dan bahan kimia yang bisa dimanfaatkan kembali atau didaur ulang, dan menghancurkan banyak kontaminan yang mungkin ada dalam aliran limbah (Hanif, 2018). Untuk penggunaan teknologi konversi thermal ini memiliki kekurangan dalam mengelolah sampah sebagai pembangkit listrik yaitu sampah yang bisa diolah hanya sampah organik saja dan terbatas, jadi untuk sampah anorganik tidak dapat digunakan untuk dikonversi secara thermal. Selain itu, konversi secara thermal ini membutuhkan biaya yang tidak sedikit atau bisa dibilang membutuhkan biaya yang tinggi. Hal itu dikarenakan alat-alat yang digunakan adalah alat-alat dengan berkapasitas yang besar dan membutuhkan lahan yang luas, sehingga untuk menggunakan thermal converter ini dibutuhkan dana yang cukup besar. Dan juga teknologi ini tidak bisa mendaur ulang sampah lama secara maksimal, sehingga perlu ditimbun terlebih dahulu di lahan yang luas dan membutuhkan waktu yang lama.

\section{Perencanaan Pembangkit Listrik Tenaga Sampah Rumah Tangga Menggunakan Teknik Thermal Converter}

Secara umum, teknologi thermal converter ini dibagi menjadi 3 tahap yaitu input berupa pemilahan sampah baik organic maupun anorganik, tahap proses meliputi pemusnahan sampah, penyimpanan uap panas, dan kemudian uap digunakan sebagai sumber penggerak turbin di dalam generator. Hasil yang diperoleh kemudian berupa sumber energy listrik. Beberapa rencana dalam membangkitkan sumber tenaga listrik dari sampah rumah tangga menggunakan teknik termal converter:

1) Compacting Truck

Compacting truck merupakan truk dengan fungsi sebagai pengumpul atau pengangkut sampah. Truk sampah ini digunakan untuk mengangkut sampah organic dengan kapasitas $15 \mathrm{~m}^{3}$. Truk akan memuat sampah kemudian truk akan memindahkan di tempat pengumpulan sampah sementara dan akan di derek dengan overhead crane. Berikut merupakan gambar dari compacting truck.

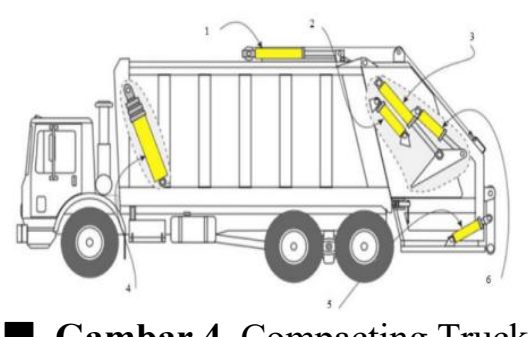

_ Gambar 4. Compacting Truck

(Sumber: Voicu, et al., 2019)

\section{2) Overhead Crane}

Overhead Crane merupakan kombinasi dari struktur dan rangka derek yang terpisah, digunakan untuk mengangkat dan memindahkan beban yang dapat digantung secara bebas atau dihubungkan ke derek itu sendiri. Alat ini digunakan untuk mengangkut sampah dan memilah sampah, serta memindahkan sampah yang terdapat di tempat penampungan sampah sementara ke tempat pemusnahan sampah dengan menggunakan overhead crane. Adapun kegunaan lainnya bisa memilah sampah yang dapat didaur ulang. Berikut merupakan gambar dari overhead crane. 


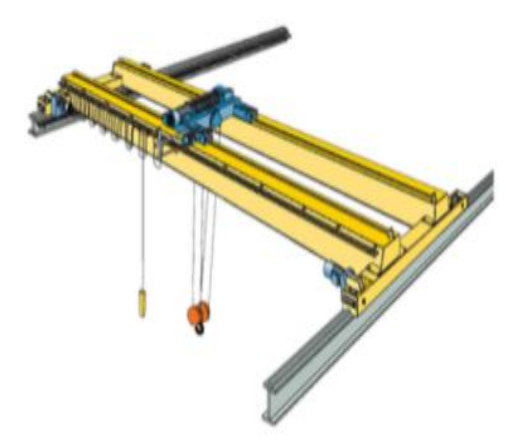

Gambar 5. OverHead Crane

(Sumber: PT. Karya Master Mandiri Indonesia, 2021)

3) Mesin Penghancur dan Penyayat Sampah

Mesin ini digunakan pada saat sampah akan dimasukkan ke ruang pembakaran supaya lebih terurai dan mempermudah proses pembakaran. Setelah masuk ruang pembakaran sampah tersebut akan cepat terbakar dan suhu dari thermal converter akan berada pada titik $1700 \mathrm{C}$.

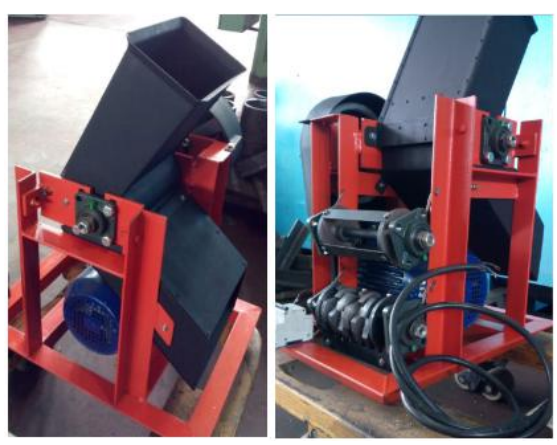

_ Gambar 6. Mesin Penghancur atau Penyayat Sampah

(Sumber: Anggry dan Subhkan, 2017)

4) Thermal Converter

Arti dari alat ini berupa penukar kalor, yang mana fungsi utama dari alat ini adalah mengubah limbah menjadi panas melalui pembakaran. Dalam proses ini, uap air diinjeksikan untuk pendinginan, sehingga menghasilkan uap berkalori tinggi yang betekanan uapnya sangat panas. Berikut merupakan gambar dari Thermal Converter.

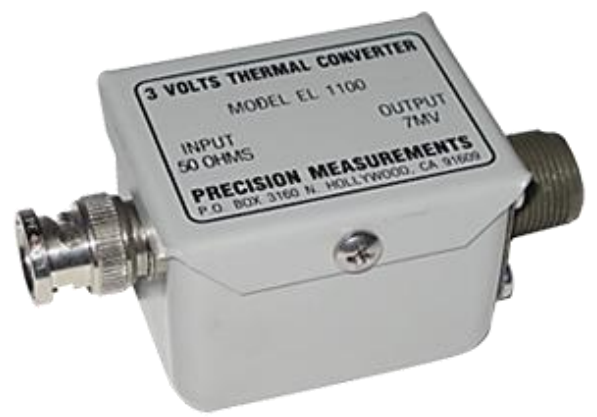

口_Gambar 7. Thermal Converter

(Sumber: https://www.measure-tech.com/tvc.html)

5) Boiler

Boiler imerupakan alat yang menyerap uap panas yang dihasilkan dari pembakaran sampah. Uap panas kemudian berlanjut yang kemudian akan didinginkan dengan penyemprotan air secara berkala. Berikut merupakan gambar dari alat boiler. 


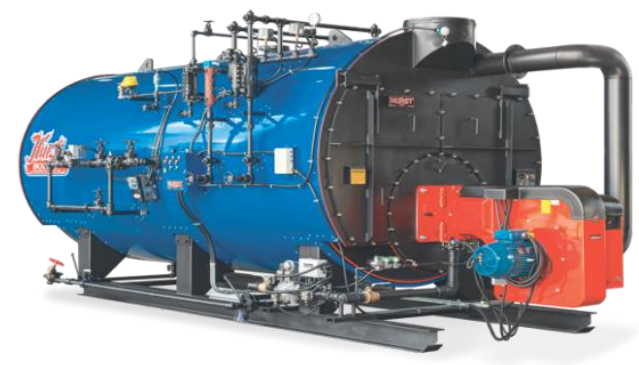

Gambar 8. Boiler

(Sumber: https://www.hurstboiler.com/boilers/scotch_marine/series_500)

6) Turbin

Turbin merupakan alat yang digunakan sebagai penggerak generator yang awalnya digerakkan oleh tenaga uap kemudian boiler akan menampungnya. Berikut merupakan gambar dari alat turbin.

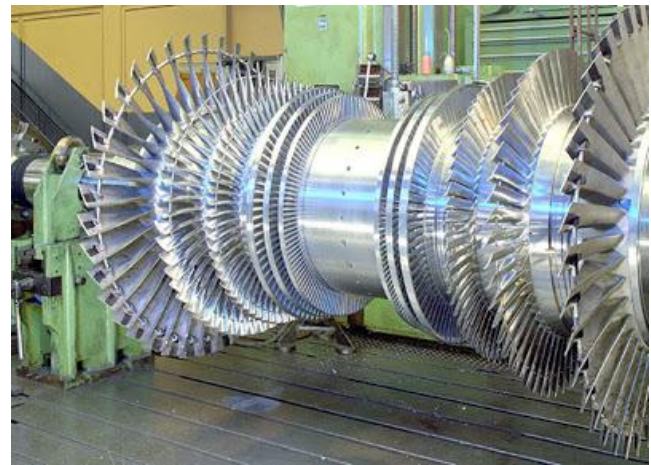

Gambar 9. Turbin

(Sumber: Dunia Mesin, 2021)

7) Generator

Generator merupakan alat yang digunakan sebagai penghasil daya listrik yang dalam pergerakannya akan digerakkan oleh turbin. Berikut merupakan gambar dari alat berupa generator.

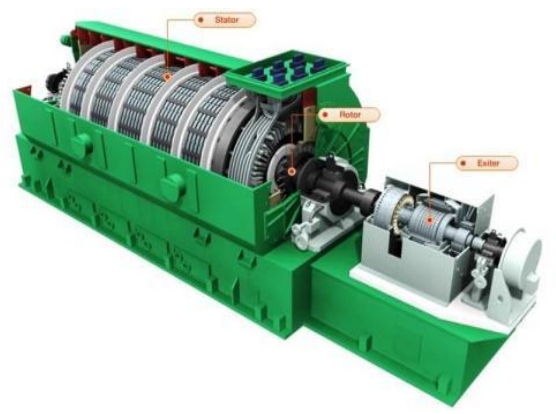

Gambar 10. Generator (Sumber: Rakhman, 2020)

\section{Potensi Energi Listrik Sampah Rumah Tangga yang Dihasilkan Dengan Teknologi Thermal Converter}

Menurut Partha (2010) menjelaskan bahwa dengan menggunakan teknologi Thermal Converter, dengan sampah rumah tangga berupa sampah organic yang dipakai sebesar 204 ton/hari atau setara dengan 237.093,33 $\mathrm{kWh}$ /hari untuk 1 pembangkit. Menghasilkan potensi sumber energy listrik sebesar $6 \mathrm{MW}=144 \mathrm{MWh}$ dengan efisiensi yang digunakan dalam pembangkitan ini sebesar $30 \%$. Sedangkan, menurut Nugraha et al., (2020) menjelaskan dalam penelitiannya bahwa dengan menggunakan sampah rumah tangga sebesar 201.594,6433 $\mathrm{kWh} /$ hari akan menghasilkan potensi sumber energy listrik sebesar 36.287,0064 kWh/hari yang jika dikonversikan ke dalam MW sebesar 36,287 MWh dengan efisiensi pada tiap pembangkitnya berupa $80 \%$ untuk efisiensi boiler, $25 \%$ untuk efisiensi turbin uap, dan $90 \%$ untuk efisiensi dari generator. 
Berikut merupakan tabel 3. Perbandingan data yang diperoleh berdasarkan pada ulasan di atas

Tabel 3. Perbandingan Data

\begin{tabular}{|c|c|c|}
\hline Teknik yang digunakan & $\begin{array}{c}\text { Sampah Rumah Tangga } \\
\text { (kWh/hari) }\end{array}$ & $\begin{array}{c}\text { Potensi Sumber energy } \\
\text { listrik yang dihasilkan } \\
\text { (MWh) }\end{array}$ \\
\hline Teknologi Thermal & $237.093,33$ & 144 \\
\cline { 2 - 3 } Converter & $201.594,6433$ & 36,287 \\
\hline
\end{tabular}

Berdasarkan data dari tabel 3. Perbandingan data tersebut, dapat dibandingkan bahwa apabila dengan menggunakan teknik teknologi thermal converter dengan semakin banyak penggunaan sampah rumah tangga yang dipakai akan menghasilkan semakin banyak pula potensi sumber energy listrik yang diperoleh. Hasil yang diperoleh ini, diikuti pula dengan efisiensi yang bekerja untuk tiap teknologi thermal converter yang digunakan.

\section{KESIMPULAN DAN SARAN}

Dari pembahasan hasil penelitian yang dilakukan menunjukkan bahwa pengelolaan sampah rumah tangga menggunakan teknik thermal converter sangat berpotensi untuk menjadikan sampah rumah tangga sebagai sumber energy listrik. Dimana dari masalah penekanan penumpukan sampah rumah tangga yang kurang dikelola dengan baik berpotensi besar dalam pemenuhan sumber energy listrik yang aman bagi lingkungan. Potensi yang dihasilkan dari penggunaan teknologi thermal converter ini menghasilkan energy listrik yang semakin besar dengan penggunaan jumlah sampah rumah tangga yang semakin banyak juga. Saran untuk artikel ini semoga dalam penulisan artikel selanjutnya menjadi lebih baik lagi dan berpedoman pada jurnal - jurnal internasional.

\section{DAFTAR PUSTAKA}

[1]. Anggry, A., dan Subkhan. 2017. Analisis Efisiensi Hasil Pencacahan Terhadap Tipe Pencacah dan Material Sampah. Jurnal MANUTECH. 9 (2): 60-88.

[2]. Anima, "Apakah Anda Benar-Benar Mengerti Apa Itu Limbah Organik", 2018.Internet: https://www.yessun.com/id/chinese-taiwan-do-you-really-know-what-organic-waste-is $\% 3 \mathrm{~F}+/$. [15 Mei 2021]

[3]. Gunawan, Y., L. Karimunua, R. Balaka, B. Sudia, L. O. Magribi, L. K. Mangalla, Kadir, Abd. Kadir, dan Nasrul. 2019. Energi Terbarukan Dari Sampah Plastik Di TPA Puuwatu Dengan Memanfaatkan Teknologi Pirolisis Guna Mendukung Masyarakat Mandiri Energi Di Kota Kendari. Seminar Nasional Teknologi Terapan Berbasis Kearifan Lokal (SNT2BKL). 1 (1).

[4]. Hariningrum, R., dan S. B. Utomo. 2020. Pemanfaatan Limbah Sampah Sebagai Energi Alternatif Pembangkit Tenaga Listrik Di Semarang. Marine Science and Technology Journal. 1(1): 30-37.

[5]. Hanif, M. 2018. Aplikasi Teknologi Termal Untuk Pengolahan Sampah. Prosiding Seminar Nasional dan Konsultasi Teknologi Lingkungan. 135 - 144.

[6]. Hust Boiler, "Hurst Series 500", 2021. Internet: https://www.hurstboiler.com/boilers/scotch marine/series 500. [15 Mei 2021]

[7]. Indah, A. B. R., S. Bahri, Mulyadi, R. Hanafi, S. Asmal, F. Mardin, M. Rusman, I. Bakri, Nilda, D. R. Mudiastuti, S. Mangenre, I. Setiawan, S. Parenreng, M. A. Darmawan, K. Amar, dan N. I. Syamsul. 2020. Sosialisai Pengelolaann Sampah Sebagai Bahan Bakar Untuk Pembangkit Listrik Tenaga Sampah (PLTSa) dengan System Strategic Partner. TEPAT Jurnal Teknologi Terapan untuk Pengabdian Masyarakat. 3 (2): 56- 64.

[8]. Measure Tech Inc, "High Voltage Thermal Converter", 2018. Internet: https://www.measuretech.com/tvc.html. [15 Mei 2021]

[9]. Mesin, D, “Turbin Uap", 2021. Internet: http://ridomanik.blogspot.com/2013/07/turbinuap.html. [15 Mei 2021]

[10]. Monice, dan Peinov. 2016. Analisis Potensi Sampah Sebagai Bahan Baku Pembangkit Listrik Tenaga Sampah (PLTSA) Di Pekanbaru. Jurnal SainETIn (Jurnal Sain, Energi, Teknologi \& Industri). 1 (1): 9-16. 
[11]. Nugraha, C. S., A. A. Darda, dan W. F. Hermawan. 2020. Pengelolaan Sampah Melalui Empowerment Masyarakat Dengan Perencanaan Pembangkit Listrik Tenaga Sampah Teknik Thermal Converter Di TPST Piyungan. Jurnal Ilmiah Penalaran dan Penelitian Mahasiswa. 4 (1): 20-28.

[12]. Partha, C. G. I. 2010. Penggunaan Sampah Organik Sebagai Pembangkit Listrik Di TPA Suwung-Denpasar. Teknik Elektro. 9 (2): 152-158.

[13]. PT. Karya Master Mandiri Indonesia, "Mesin Alat Berat - OverHead Crane", 2021. Internet: $\quad$ http://www.kmmigroup.com/WEB001/index.php/en/sort-learning/learning-bidpaa/374-mesin-alat-berat-overhead-crane.html. [15 Mei 2021]

[14]. Pujotomo, I. 2017. Potensi Pemanfaatan Biomassa Sekam Padi Untuk Pembangkit Listrik Melalui Teknologi Gasifikasi. Jurnal Energi dan Kelistrikan. 9 (2): 126-135.

[15]. Putri, N. H, "Limbah Anorganik Ada di Sekitar Kita, Ini Jenis dan Cara Tepat Mengolahnya", 2020. Internet: https://www.sehatq.com/artikel/limbah-anorganik-ada-di-sekitar-kita-ini-jenisdan-cara-tepat-mengolahnya. [15 Mei 2021]

[16]. Rakhman, A., "Pemeliharaan Generator", 2020. Internet: https://rakhman.net/electricalid/pemeliharaan-generator/. [15 Mei 2021]

[17]. Samsinar, R., dan K. Anwar. 2018. Studi Perencanaan Pembangkit Listrik Tenaga Sampah Kapasitas 115 KW (Studi Kasus Kota Tegal). Jurnal Elektum. 15 (2): 33-40.

[18]. Suhada, R.T, dan I. Al-Mahdy. 2017. Analisis Potensi Sampah Sebagai Sumber Energi Pembangkit Listrik Tenaga Sampah dan Produk Kreatif Untuk Mendukung Pariwisata (Studi Kasus di Kepulauan Seribu). Jurnal PASTI. 11 (3): 245-255.

[19]. Surma, U., A. Natio, S. Harahap, dan L. O. M. Firman. 2020. Analisa Pemanfaatan Sampah Perkotaan Untuk Pembangkit Listrik Di TPA Ciniru Kabupaten Kuningan. Teknobiz: Jurnal Ilmiah Program Studi Magister Teknik Mesin. 10(1): 7-12.

[20]. Sulistiorini, I. N, "Pengelolaan Sampah Rumah Tangga", 2019. Internet: https://dlhk.jogjaprov.go.id/pengelolaan-sampah-rumah-tangga. [15 Mei 2021]

[21]. Voicu, G., M. Lazea, B. S. Zabava, P. Tudor, dan V. Moise. 2019. Cinematical Analysis of The Pre-Taking and Pre-Compacting Mechanisms Of Some Garbage Trucks. Journal of Engineering Studies and Research. 25 (2): 56-62.

[22]. Wardana, I. W., Junaidi, R. F. Soeroso, dan P. S. Akbar. 2012. Sampah Untuk Energi: Kelayakan Pemanfaatan Limbah Organik Dari Kantin Di Lingkungan Undip Bagi Produksi Energi Dengan Menggunakan Reaktor Biogas Skala Rumah Tangga. Jurnal PRESIPITASI. 9 (2): 79-83.

[23]. Monice, and . Perinov. 2017. 'ANALISIS POTENSI SAMPAH SEBAGAI BAHAN BAKU PEMBANGKIT LISTRIK TENAGA SAMPAH (PLTSA) DI PEKANBARU'. SainETIn 1 (1): 9-16. https://doi.org/10.31849/sainetin.v1i1.166.

[24]. Ambabunga, Yusri. 2019. 'Analisis Pembangkit Energi Listrik Dengan Sumber Energi Baru dan Terbaharukan'. Jurnal Pendidikan Fisika 2: 4.

[25]. Partha, Cokorde Gede Indra. 2010. 'PENGGUNAAN SAMPAH ORGANIK SEBAGAI PEMBANGKIT LISTRIK DI TPA SUWUNG - DENPASAR' 9: 7.

[26]. Sari, Fitria Novita. 2021. 'Alternatif Pemanfaatan Sampah Organik Sebagai Konservasi Sumber Energi Listrik'. Jurnal Fokus Elektroda: Energi Listrik, Telekomunikasi, Komputer, Elektronika dan Kendali) 6 (3): 165. https://doi.org/10.33772/jfe.v6i3.18994.

[27]. Suhada, R.T dan Al-Mahdy, I. 2016. 'ANALISIS POTENSI SAMPAH SEBAGAI SUMBER ENERGI PEMBANGKIT LISTRIK TENAGA SAMPAH DAN PRODUK KREATIF UNTUK MENDUKUNG PARIWISATA (STUDI KASUS DI KEPULAUAN SERIBU). 